\title{
Модели здоровьесбережения в российских региональных СМИ
}

Татьяна Фролова

Елизавета Стрига

Актуальность исследований, результаты которых представлены в настоящей статье, определяется потребностью общества в эффективных медийных практиках здоровьесбережения, особо значимых для региональных СМИ ввиду их типологического статуса, обусловливающего близость к аудитории и знание ее потребностей и интересов. Практики газет, отобранных для анализа, достаточно вариативны. В статье отражено разнообразие моделей здоровьесбережения, показаны сходства и различия, представлены оценки практик с позиций соотношения должного и реального, сформулированы рекомендации.

Ключевые слова: здоровье, здоровьесбережение, здоровый образ жизни, региональные газеты, сравнительный анализ.

DOI: 10.30547/mediaalmanah.5.2020.6073

@ Фролова Татьяна Ивановна доктор филологических наук, профессор кафедры периодической печати факультета журналистики МГУ имени М.В. Ломоносова (г. Москва, Россия), t_frolova@bk.ru

@ Стрига Елизавета Андреевна преподаватель кафедры периодической печати факультета журналистики МГУ имени М.В. Ломоносова (г. Москва, Россия), striga_elizaveta@mail.ru
В России последних десятилетий сформировался рынок медицинскихи идоровьесберегающих технологий и услуг: «производители», «продавцы», «посредники» и «покупатели» здоровья изменили привычные представления о здоровом образе жизни. Биомедицинская модель здоровья уступает место социокультурной, что означает перенос акцента с лечения на профилактику заболеваний, на понимание здорового образа жизни (ЗОж) как особой жизненной философии, формирующей сознание человека и обеспечивающей расширение его экзистенциальных возможностей. В то же время ситуацию, сложившуюся между декларациями и фактическим положением в сфере здоровьесбережения, нельзя считать удовлетворительной. Наблюдается разрыв между все более расширяющимся коммуникационным полем, т.е. между растущими возможностями и фактическим незначительным прогрессом в ведении 30Ж населением России, в неразвитой личной ответственности за свое здоровье.

В этом направлении у региональных СМИ, как мы полагаем, должна быть своя собственная роль, стратегии и возможности в силу особенностей, определяемых их типологическим статусом. Объективно значимы и важны преференции в виде допустимости значительных объемов публикаций, близости к аудитории, доступности 
источников, возможностей обратной связи, мобилизации общественных структур, скорости реакции на запросы аудитории, включенности в повседневную жизнь аудитории. Непосредственным объектом анализа стали областные газеты в их аналоговых и сетевых формах. Такой выбор обусловлен их "срединным» положением в отечественной медиасистеме между федеральными и местными изданиями, что, на наш взгляд, позволяет совмещать как глубинные, сущностные компоненты 30ж, так и прагматические аспекты и тем самым стремиться к концептуальности этой профильной повестки. Тематически универсальные, эти СМИ дают представление о месте и роли здоровьесбережения в общей картине жизненных практик россиян.

Методологически наше исследование строилось на сопоставлении должного в области продвижения ценностей $30 \%$, представление о котором сформировалось на основе обращения к теоретическим, документальным и статистическим источникам, и реального опыта, выявленного в процессе эмпирического исследования.

Теоретической основой наших исследований стали современные концепции здоровья и здоровьесбережения. Эта тематика активно разрабатывается в мировой и отечественной науке в самых широких областях знания. Современное и полное представление о феномене 30Ж в процессе длительного исторического периода его становления нашло отражение в многосоставности подходов, множественности определений, полноте структуры (компонентов), выявлении рисков и пр. (Аристотель, 1997; Афонюшкин, 2017; Базелюк, 2008; Бредихина, 2006; Бриленок, 2017; Гален Клавдий, 1971; Гиппократ, 1998; Кант, 1994; Касимов, 2017; Конфуций, 1999; Образцова, 2010; Платон, 1994; Прохоров, 2011; Стрига, 2018; Шустер, 2005). Зарубежные исследования ЗОЖ помимо их общей ценностной направленности концентрируют внимание на структуре феномена, на описании значимости его компонентов, используют «индекс ЗОЖ», разрабатывают специализированные программы для обучения школьников и методики для продвижения 30ж через социальные сети (Andrew, 2011; Borowiec, 2016; Bothmer, Fridlund, 2005; Brouwer, Brug, 2011; Chiarelli, Fulcheri, 2016; Danylevich, Hribovska, 2015; Ford, 2019; Jacobson, Kelly, 2011). Многочисленны зарубежные и отечественные документы, фиксирующие озабоченность общества состоянием здоровья граждан, необходимостью его укрепления как основного социального капитала ${ }^{1}$. Собственно медийные источники, составившие методологическую основу наших исследований, включали работы по базовым функциям СМИ и социальной журналистики, методам и жанрам, аксиологии и деонтологии журналистики (Беленькая, 2013; Вартанова, 2013, 2017; Лазутина, 2011, 2017; МакКуэйл, 2014; Прохоров, 2011; Фомичева, 2012; Фролова, 2014; Шкондин, 2002). Многие исследования посвящены анализу деятельности региональных СМИ (Гладкий, Чистобаев, 2002; Киршин, 2006; Лебедев, 2011; Мурзин, 2008; Новак, 2018; Свитич, Смирнова, Ширяева, Шкондин, 2015; Фокина, 2013).

Эмпирическая база сформирована по результатам двухэтапного исследования, проведенного в 2016-2019 гг.:

- опрос региональных журналистов «Профессиональный опыт российских журналистов в продвижении ценностей здорового образа жизни (ЗОЖ) в российских СМИ», имевший целью выявить уровень готовности журналистов к продвижению ценностей 30Ж. Опрошено 140 журналистов из 53 субъектов РФ от 21 года до 75 лет; для анализа результатов использован пакет программ статистического анализа социологической информации - SPSS.

- контент-анализ региональной прессы «Медиадискурс здоровьесбережения в региональных СМИ», позволивший исследовать реальную практику региональных газет. Рассмотрено 2044 журналистских 
текста в девяти областных газетах по девяти категориям анализа, включавшим, в частности, информационные поводы, тематику, жанры, типы аргументации и др. Сопоставление должного и реального было осуществлено по итогам теоретического и эмпирического этапов исследования, предпринята попытка сравнительного анализа, включающая несколько уровней: сравнение практик газет отдельных регионов и выяснение степени сходств и различий, определяющих характер вариативности повесток 30ж; сравнение средних показателей по двум эмпирическим исследованиям (опрос и контент-анализ) и определение уровня совпадений между сознанием и реальной практикой журналистов. Сравнительный анализ помог выявить достижения и недостатки в практике газет и сформулировать рекомендации по повышению их эффективности, которые и составили предмет данной статьи.

\section{Вариативность повесток 30\%: сопоставление практик региональных газет}

В исследовании участвовали журналисты разного пола, возраста, базового образования. Существенно значим и тот факт, что это были газеты, представлявшие различные регионы страны, географически далекие, исторически неодинаковые, творчески самобытные. В их практике немало как сходств, так и различий (см. табл. 1).

Сходства (общие черты) обусловлены целостностью, предметной определенностью, функциональной направленностью объекта рассмотрения и также типологическим профилем анализируемых изданий; различия (частные проявления) - особенностями: территориальными, структурноорганизационными, но в большей степени личностными, индивидуальными характеристиками работающих в них журналистов. Тему здоровья, в региональной газете, как правило, ведет один журналист; при этом он нередко совмещает эту специализацию с другими компонентами общей гуманитарной повестки. Естественно, свои конкретные задачи профессионалы понимают и реализуют по-разному, что и обусловливает вариативность повесток. Далее выборочно представлены наиболее значимые категории анализа.

Инфоповоды. Особенности внимания к этому компоненту деятельности задаюттон в формировании всей производственной цепочки и прямо влияют как на тематику, так и на жанры публикаций.

Таблица 2 показывает существенную роль инфоповодов, созданных властными органами и иными структурами и реализованных в виде мероприятий, событий, решений, - таковых более 70\%. Однако колебания в их выборе также существенны: мероприятия - от 24\% до 53\% в категории «Мероприятие», от 4\% до 27\% - в категории «Новый закон, решение правительства». Это говорит о том, что названные инфоповоды отражают деятельность властей по продвижению 30Ж, журналисты на них реагируют (что закономерно), однако не являются инициаторами этих поводов. Можно заключить, что власти более активны, чем журналисты, о чем свидетельствует показатель 70\%. Однако уровень «пассивности» здоровьесберегательной повестки в регионах разный: в Архангельске таких публикаций четверть от всего массива, а в Ростове-на-Дону и Тюмени их более половины. Следовательно, журналисты Архангельска в большей степени склонны к самостоятельности, к поиску достойных поводов.

Существенную роль, хотя и не самую важную, в практике всех газет играет повод, наиболее тесно связанный с проблематикой здоровья, - «Советы, мнения экспертов, прогнозы» (почти 20\%). Он мог бы использоваться более активно, в разнообразных и убедительных формах. В отношении к нему особенно заметны колебания - от 30,1\% в Омске до $11,1 \%$ в Пскове. Едва ли причина сложившегося положения 
Таблица 1. СМИ - объекты исследования (абс.)

\begin{tabular}{|l|l|c|}
\hline \multicolumn{1}{|c|}{ сми } & \multicolumn{1}{|c|}{ Регион } & \multicolumn{1}{|c|}{$\begin{array}{c}\text { Кол-во } \\
\text { публикаций }\end{array}$} \\
\hline Правда Севера & Архангельск & 132 \\
\hline Вечерний Новосибирск & Новосибирск & 187 \\
\hline Кировская правда & Киров & 73 \\
\hline Наше время & Ростов-на-Дону & 173 \\
\hline Омская правда & Омск & 156 \\
\hline Псковская правда & Псков & 253 \\
\hline sаkhalin.info & Сахалинская область & 640 \\
\hline Тюменская область сегодня & Тюмень & 205 \\
\hline Хабаровский край сегодня & Хабаровск & 225 \\
\hline
\end{tabular}

Таблица 2. Инфоповоды, используемые для освещения проблематики ЗОЖ (\%)

\begin{tabular}{|c|c|c|c|c|c|c|c|c|c|c|}
\hline Виды инфоповодов & 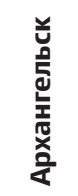 & 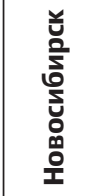 & $\begin{array}{l}\frac{0}{0} \\
\frac{2}{\Sigma}\end{array}$ & 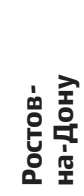 & ǔ & $\begin{array}{l}\text { o̊ } \\
\text { uㅡㄷ }\end{array}$ & 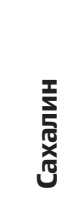 & 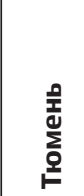 & 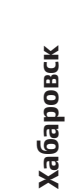 & 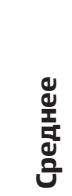 \\
\hline Мероприятие & 24,2 & 26,5 & 30,2 & 54,9 & 39,7 & 53,8 & 37,6 & 54,7 & 28,9 & 39,9 \\
\hline Событие & 21,2 & 29,9 & 19,0 & 21,5 & 9,0 & 15,4 & 19,9 & 20,0 & 12,9 & 18,9 \\
\hline $\begin{array}{l}\text { Новый закон, решение } \\
\text { правительства }\end{array}$ & 15,2 & 25,9 & 14,3 & 4,0 & 10,3 & 5,9 & 7,5 & 4,4 & 27,1 & 11,6 \\
\hline $\begin{array}{l}\text { Советы, мнение } \\
\text { экспертов, прогнозы }\end{array}$ & 27,3 & 13,7 & 28,6 & 12,1 & 30,1 & 11,1 & 20,0 & 7,8 & 24,4 & 18,5 \\
\hline Анонсирование & 5,3 & 3,0 & 7,9 & 5,2 & 5,1 & 9,1 & 10,0 & 10,2 & 4,0 & 7,4 \\
\hline Зарубежный опыт & 6,8 & 1,0 & - & 2,3 & 5,8 & 4,7 & 5,0 & 2,9 & 2,7 & 3,7 \\
\hline
\end{tabular}

дел в недостатке экспертов, когда речь идет об областном городе. В обращении к этому поводу требуются желание расширить рамки повестки и опыт журналиста; этот повод гораздо «активнее» и «самостоятельнее» по потенциалу, чем, например, спортивное соревнование. Глядя на цифры, мы можем констатировать более значимый личный вклад журналистов названных городов в строительство контента 30Ж.

Что же касается презентации зарубежного опыта, то здесь картина неудовлетворительная почти для всех газет. Известно, что сохранением и укреплением здоровья в развитых странах мира занимаются давно и активно; соответствующий контент составляет важную часть в повестке СМИ этих стран, в особенности в местных изданиях.
Не вдаваясь в подробный анализ причин (они разнообразны), отметим, что культура здоровья у наших европейских соседей развита лучше, показатель продолжительности жизни выше на целый десяток лет. В современных условиях медиакоммуникаций изучение их опыта вплоть до прямых заимствований возможно и могло бы быть полезным. В этом отношении некоторую активность проявили только журналисты Сахалина и Тюмени.

Целостный анализ повесток по информационным поводам приводит к таким наблюдениям: Архангельск («Правда Севера»), Новосибирск («Вечерний Новосибирск»), Хабаровск («Хабаровский край сегодня») - журналисты этих газет стремятся к разнообразию и сбалансированности 
информационных поводов, которые должны вести к такой же сбалансированной и насыщенной повестке; Киров («Кировская правда»), Ростов-на-Дону («Наше время»), Омск («Омская правда»), Тюмень («Тюменская область сегодня») в своей информационной активности достаточно пассивны, им следует быть более предприимчивыми, а также повышать свои предметные компетенции, чтобы активнее привлекать экспертов.

Если же дать общую характеристику инфоповодов в региональных газетах, то напрашивается вывод о недостаточной активности журналистов в их выборе, об избыточном следовании постановочным мероприятиям, о недостатке внимания к специалистам и зарубежному опыту.

Тематика. Гипотетически просчеты в выборе инфоповодов должны отразиться в повестке, но возможны и расширения, выход за пределы заданного (см.табл. 3).

Данные, представленные в таблице, позволяют сделать вывод, что тематика гораздо разнообразнее непосредственных поводов, что можно оценить как творческое достижение. В то же время некоторая несбалансированность заметна и здесь. Так, около 60\% публикаций связаны с занятиями спортом и иными физическими методами сбережения здоровья. Каким же должно быть соотношение компонентов? Есть ли вообще ответ на этот вопрос? Надо сказать, что теоретические источники не определяют правильный баланс, они лишь называют компоненты - видимо, полагая, что компоненты должны быть сбалансированы. О региональных повестках этого не скажешь. Приоритет отдается спорту и спортивным мероприятиям, в явном меньшинстве психологические основы здоровья («все болезни от нервов»), правильное питание (30\% россиян страдают избыточным весом; распространен сахарный диабет), режим труда и отдыха, отказ от вредных привычек (в числе главных рисков здоровья россиян, как известно, курение и алкоголизм занимают ведущие места). Недостаточны те же 10\%, отведенные теме необходимости регулярных медицинских осмотров. Мы видим, что выявленная несбалансированность во многом обусловлена выбором инфоповодов.

В то же время следует обратить внимание на различия в практике газет. Спортивно-профилактические мероприятия представлены 12\% в Архангельске и 47\% в Пскове; влияние бытовых условий - 18\% в том же Архангельске и 1,6\% в Кирове; отказ от вредных привычек - 14,7\% в Хабаровске и 2,6\% в Омске. Крайне недостаточным представляется внимание к образу жизни, к повседневности, к семье, отдыху как важнейшим факторам здоровья во всех газетах. Очевидно, что региональные журналисты достаточно односторонне понимают здоровый образ жизни и в значительной мере сводят его к общественным спортивным мероприятиям, в которых принимает участие меньшинство населения. Образ жизни в целом, культура здоровья и ценность здоровья во многом остаются за пределами публичной коммуникации.

Сравнивая практику отдельных газет, снова можно выделить архангельскую, новосибирскую и хабаровскую газеты: в них названные просчеты не так очевидны, их повестки наиболее сбалансированы.

Жанровая структура. Связанная и с инфоповодами, и с тематикой, она отражает глубину, аргументированность и доказательность, использование разнообразных выразительных средств и общую направленность повесток (см. табл. 4).

Исследование показало, что жанровая палитра региональных изданий в аспекте продвижения ценностей ЗОЖ достаточно разнообразна. Это можно приветствовать в условиях повсеместной унификации текстовых форм. Как оказалось, региональные газеты еще не готовы отказаться от жанровых различий и стремятся к многогранному и стереоскопическому видению отображаемого объекта. В случае с ЗОЖ это 
Таблица 3. Тематика (компоненты) 30ж (\%)

\begin{tabular}{|c|c|c|c|c|c|c|c|c|c|c|}
\hline Компоненты ЗОЖ & 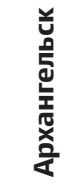 & 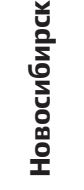 & $\frac{\infty}{\frac{0}{2}}$ & 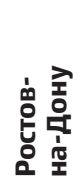 & ò & 迆 & 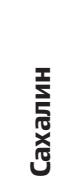 & 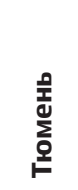 & 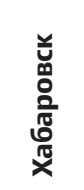 & 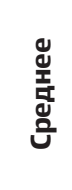 \\
\hline $\begin{array}{l}\text { Профилактика } \\
\text { здоровья (акции, } \\
\text { мероприятия, } \\
\text { постановления) }\end{array}$ & 12,1 & 36,0 & 36,4 & 45,2 & 42,9 & 47,0 & 42,5 & 45,0 & 30,6 & 39,7 \\
\hline Спорт, физкультура & 15,2 & 27,0 & 12,6 & 4,6 & 24,4 & 17,0 & 22,5 & 18,5 & 15,6 & 18,9 \\
\hline $\begin{array}{l}\text { Медицина (советы } \\
\text { медиков } \\
\text { и фармацевтов) }\end{array}$ & 18,2 & 8,0 & 27,0 & 13,9 & 7,0 & 7,5 & 7,5 & 10,5 & 7,1 & 9,6 \\
\hline Психология & 0,8 & 2,0 & 1,6 & 4,0 & 2,6 & 3,6 & 1,9 & 3,0 & 2,2 & 2,4 \\
\hline Правильное питание & 5,3 & 7,0 & 4,8 & 2,9 & 8,3 & 7,1 & 2,7 & 3,5 & 11,1 & 5,3 \\
\hline $\begin{array}{l}\text { Бытовые условия, } \\
\text { среда, семья }\end{array}$ & 18,1 & 11,5 & 1,6 & 12,1 & 6,4 & 5,1 & 10,0 & 7,5 & 11,6 & 9,6 \\
\hline Отдых. Увлечения & 15,2 & 3,5 & 9,6 & 9,2 & 4,5 & 6,3 & 4,8 & 5,5 & 6,7 & 6,3 \\
\hline $\begin{array}{l}\text { Доброжелательные } \\
\text { отношения в семье }\end{array}$ & 3,0 & 0,5 & 1,6 & 5,2 & 1,3 & 2,8 & 0,6 & 2,0 & 0,4 & 1,6 \\
\hline $\begin{array}{l}\text { Отказ от вредных } \\
\text { привычек }\end{array}$ & 12,1 & 4,5 & 4,8 & 2,9 & 2,6 & 3,6 & 7,5 & 4,5 & 14,7 & 6,6 \\
\hline
\end{tabular}

Таблица 4. Жанровая структура повесток ЗОЖ (\%)

\begin{tabular}{|c|c|c|c|c|c|c|c|c|c|c|}
\hline Жанры & 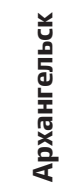 & 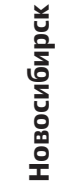 & $\begin{array}{l}\stackrel{0}{\circ} \\
\stackrel{2}{\Sigma}\end{array}$ & 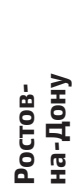 & ב̆ & $\begin{array}{l}\text { ơ } \\
\text { 름 }\end{array}$ & 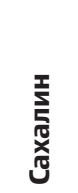 & 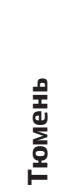 & 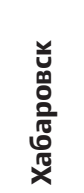 & 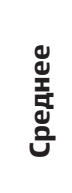 \\
\hline Краткая новость & 18,2 & 25,8 & 9,5 & 20,8 & 19,9 & 40,8 & 19,3 & 39,9 & 26,2 & 25,3 \\
\hline Расширенная новость & 21,1 & 24,9 & 11,1 & 22,5 & 16,0 & 28,4 & 24,3 & 17,6 & 26,7 & 23,2 \\
\hline Репортаж & 15,2 & 22,9 & 28,6 & 13,9 & 24,9 & 8,3 & 19,8 & 15,6 & 15,6 & 17,7 \\
\hline Статья & 3,8 & 4,5 & 9,5 & 6,9 & 10,3 & 4,3 & 7,5 & 5,4 & 6,2 & 6,5 \\
\hline $\begin{array}{l}\text { Просветительский } \\
\text { текст }\end{array}$ & 2,3 & 5,6 & 4,8 & 11,0 & 3,2 & 4,7 & 9,2 & 6,8 & 4,4 & 6,6 \\
\hline Обозрение & 6,1 & 5,1 & 3,2 & 5,2 & 6,4 & 3,2 & 2,5 & 4,4 & 7,1 & 4,1 \\
\hline Интервью & 27,2 & 6,6 & 23,8 & 16,2 & 13,5 & 5,9 & 11,2 & 8,3 & 10,2 & 11,7 \\
\hline Очерк & 6,1 & 4,6 & 9,5 & 2,3 & 5,8 & 3,6 & 5,9 & 1,5 & 3,6 & 4,6 \\
\hline $\begin{array}{l}\text { Журналистское } \\
\text { расследование }\end{array}$ & - & - & - & 1,2 & & 0,8 & 0,3 & 0,5 & - & 0,3 \\
\hline Другое & - & - & - & - & - & - & - & - & - & - \\
\hline
\end{tabular}


важно в особенности, поскольку здесь требуются различные методы аргументации, прямое воздействие на развитие активности основной части аудитории. Унификация была бы для этой цели губительна. Мы полагаем, что, отчасти проигрывая в выборе информационных поводов и недотягивая в области сбалансированности тематической структуры, журналисты интуитивно стремятся к восполнению потерь в области использования жанров.

Превалирование информационных жанров - более 70\% - ожидаемо, исходя из примерно такого же числа инфоповодов (мероприятий, событий), однако колебания в жанровой структуре требуют комментариев. Краткая новость $(9,5-40,8 \%)$ только фиксирует событие: мы видим, что журналисты разных газет в разной степени привержены этому жанру. Возможно, часть из них не посещала описываемые события (Псков, Тюмень) и ограничилась только дежурным сообщением, в то время как другая часть заполнила информационное пространство меньшим количеством таких сообщений (Киров, Архангельск), предпочтя детали и эмоции, мотивирующее к вовлечению аудитории, в репортажах и расширенных новостях. Этих распространенных информационных форм (репортаж, интервью) в практике газет немало - примерно треть.

Статьи, просветительские тексты, очерки, обозрения требуют от журналиста значительных усилий по их подготовке. Понятно, что таких текстов не может быть много, однако важно, что они есть. А просветительских текстов (2-11\%) могло бы быть и больше - но вспомним, что эксперты как информационные источники привлекались недостаточно. Можно приветствовать интервью (Архангельск - 27\%), которое, по-видимому, дали эксперты и люди, имеющие опыт в этой области. Это может быть убедительно и привлекательно. Отметим: просветительские тексты в Архангельске немногочисленны - 2\%, но количество интервью значительно. По-видимому, журналист газеты стремился к тому, чтобы подать исходный материал не в виде прямого агитационного послания, а с разъяснениями, комментариями, уточнениями, эмоциями и т.д.

Оценивая жанровые решения газет в целом, мы все же видим различные концептуальные подходы: сбалансированные в большей (Архангельск) или меньшей (Псков) степени - т.е. убедительные, аргументированные, привлекательные, потенциально эффективные в разной степени. Окончательный же вывод позволяет выделить архангельскую газету как наиболее успешную в вопросе продвижения ценностей 30ж.

Региональные повестки 30ж, как показывает исследование, вариативны. В них немало достижений, но и просчеты также имеются: ограниченность инфоповодов, порождающая пассивность и неполноту повестки, недостаточная компетентность журналистов, ведущих эту тематику, игнорирование актуальных проблем образа жизни, препятствующих сохранению и укреплению здоровья.

\section{Профессиональные установки журналистов и практика: сходства и различия}

Сравнение результатов двух этапов эмпирических исследований также представляется важным. Имея целью формулирование практических рекомендаций для журналистов, мы хотели бы показать связь между пониманием журналистами задач в области продвижения ценностей ЗОж и реализацией этих задач на практике. Здесь мы отметили сходства и различия в результатах опроса и контент-анализа. Наиболее значимые из них представлены в сводных таблицах данных двух исследований и комментариях к ним.

Инфоповоды. Повторим, это одна из наиболее значимых категорий анализа, задающая характер всей повестки 3Ож (см. табл. 5). 
Таблица 5. Сравнение инфоповодов (\%)

\begin{tabular}{|c|l|c|c|}
\hline № & \multicolumn{1}{|c|}{ Виды инфоповодов (опрос) } & $\begin{array}{c}\text { Доля } \\
\text { в опросе }\end{array}$ & $\begin{array}{c}\text { Доля } \\
\text { в контенте }\end{array}$ \\
\hline 1 & Спортивные мероприятия & 51,4 & 39,9 \\
\hline 2 & Оздоровительные мероприятия & 20 & 18,9 \\
\hline 3 & Просвещение, совет, рекомендация & 11,4 & 18,4 \\
\hline 4 & Мотивация, зарубежный опыт & 10 & 3,7 \\
\hline 5 & Анонс/реклама мероприятий & 2,9 & 7,4 \\
\hline 6 & $\begin{array}{l}\text { Открытие сооружений, решение органа } \\
\text { власти }\end{array}$ & 1,4 & 11,6 \\
\hline 7 & Другое & 2,9 & 0,1 \\
\hline \multicolumn{2}{|l|}{ Всего } & 100 & 100 \\
\hline
\end{tabular}

Таблица 6. Сравнение компонентов тематической структуры ЗОж

\begin{tabular}{|c|l|c|c|}
\hline № & \multicolumn{1}{|c|}{ Темы публикаций } & $\begin{array}{c}\text { Доля } \\
\text { в опросе }\end{array}$ & $\begin{array}{c}\text { Доля } \\
\text { в контенте }\end{array}$ \\
\hline 1 & $\begin{array}{l}\text { Физические нагрузки (физкультура, } \\
\text { спорт, походы, группы здоровья, } \\
\text { семейные спартакиады) }\end{array}$ & 27,5 & 58,5 \\
\hline 2 & Медицина, осмотры, закаливание & 4,5 & 9,6 \\
\hline 3 & Психология & - & 2,4 \\
\hline 4 & $\begin{array}{l}\text { Правильное питание, контроль массы } \\
\text { тела }\end{array}$ & 6,0 & 5,3 \\
\hline 5 & Бытовые условия, среда, семья & 24,0 & 9,6 \\
\hline 6 & Отдых, увлечения & 8,0 & 6,3 \\
\hline 7 & Отношения с окружающими & - & 1,6 \\
\hline 8 & Отказ от вредных привычек & 30,0 & 6,6 \\
\hline 9 & Другое & - & 0,1 \\
\hline & Всего & 100 & 100 \\
\hline
\end{tabular}

Как в опросе, так и в публикациях в качестве инфоповодов доминируют организованные мероприятия (спортивные, оздоровительные), а также действия органов власти и общественных организаций. Так, этой позиции придерживается 73\% журналистов; в повестке она нашла отражение в 70\% реальных инфоповодов. Данные показывают, что журналисты прочно ориентированы на отражение мероприятий, событий, решений, которые логично связать с ЗОЖ. Другими словами, большая часть публикаций обусловлена внешними мероприятиями. В определенной степени такую ориентацию можно охарактеризовать как пассивную.
Более живой и активной можно считать примерно пятую часть публикаций: 21\% журналистов считали необходимым давать читателям просвещающую и мотивирующую информацию, в результате чего 18\% реально использованных инфоповодов - это мнения экспертов и сформулированные на их основе советы и рекомендации. Такие инфоповоды дают возможность сделать роль журналиста заметнее, его участие более осознанное, аргументация, как правило, выражена конкретнее, выразительные средства разнообразнее. Другие поводы в опросе также присутствуют, в повестке видим обращение к зарубежному опыту, хотя и крайне редкое - 
но таких поводов не более $3 \%$, а отражения в повестке они практически не нашли. В целом же приходится констатировать довольно ограниченное представление журналистов о том, что может стать поводом для обращения к теме здоровья аудитории. Ограниченность сознания предопределяет недостатки повестки. Сделать интересный, привлекательный контент на основе такого понимания довольно сложно.

Тематика. Это предположение подтвердилось в анализе повестки, в тематике публикаций лишь отчасти (см. табл. 6).

Так, в опросе респонденты отводят внешним мероприятиям треть публикаций, а в действительности их 60\% - журналисты, как видим, подвержены тенденции реагировать на внешние "раздражители» в большей степени, чем они сами считают нужным. Отдавая должное важности и значимости физических нагрузок для поддержания здоровья, они нередко упускают из вида не менее важные его компоненты. Определенно недооцениваются нравственно-психологические и аксиологические составляющие здоровья. Подчас они вообще игнорируются, хотя «модель здоровой личности» в сознании человека определяет весь его жизненный путь: психология здоровья, отношения с окружающими в опросе не называются, а в контенте занимают менее 5\%.

Важно отметить и очевидные расхождения между осознанием значимости некоторых компонентов 30ж и их отражением в повестке. Анкетирование показало, что журналисты обоих полов и всех возрастов (24\% респондентов) важнейшей компонентой ЗОЖ признают счастье в семье, а среди журналистов старше 50 лет 36\% респондентов поставили счастье в семье на первое место среди всех факторов здоровья. Контент-анализ реального содержания региональной прессы показал, что благоприятным бытовым условиям и доброжелательным взаимоотношениям в семье посвящены лишь 9,6\% публикаций. Тема общения, взаимоотношений отражена только в 1,6\% публикаций. Каковы причины? Повседневная жизнь бедна примерами? Едва ли; публикации о счастье как факторе 30Ж и счастливых семьях требуют от журналиста серьезной, вдумчивой работы, профессионализма, более высокой литературной квалификации и существенных временных и моральных затрат. В условиях цейтнота на это просто недостает ресурсов. Также и повсеместное распространение агрессии, грубости, неуважения, фактически разрушающих здоровье личности, остается вне поля зрения журналистов. Значимость культуры общения в СМИ отходит на задний план, но при этом, как все знают, «все болезни от нервов». Очевидность диссонанса не требует комментариев.

Аналогична ситуация в вопросе о вредных привычках. В анкетах 30\% журналистов проявляют оправданное, естественное беспокойство о фактическом бедственном состоянии нации, вызванном и традиционными, и всевозможными новыми, быстро распространяющимися аддикциями, - алкоголизмом, наркоманией, табакокурением, интернет-зависимостью, игроманией, некритическим телепросмотром, психогенным перееданием. Однако фактически только 6,6\% публикаций по тематике 30ж посвящены этой проблеме, что совершенно не соответствует объективной потребности аудитории. Не углубляясь в анализ причин, можем предположить следующее: власти, плотно интегрированные в работу местных СМИ, не желают обострять проблему, которую не умеют решать и не хотят портить имидж региона; журналисты не обращаются к этой стороне жизни населения, так как материалы о проблемах аддикций не заказываются или отклоняются; читателям неприятно «смотреть в зеркало» нелицеприятной стороны своей жизни. Не секрет и то, что у нас непозволительно терпимо относятся к вредным привычкам, считая их «национальной особенностью», а не ущербом для здоровья. В результате 
Таблица 7. Сравнение жанров публикаций (\%)

\begin{tabular}{|c|l|c|c|}
\hline № & \multicolumn{1}{|c|}{ Жанры публикаций } & $\begin{array}{c}\text { Доля } \\
\text { в опросе }\end{array}$ & $\begin{array}{c}\text { Доля } \\
\text { в контенте }\end{array}$ \\
\hline 1 & Репортаж & 30,0 & 17,7 \\
\hline 2 & Краткая новость & 22,9 & 25,2 \\
\hline 3 & Статья & 18,6 & 6,5 \\
\hline 4 & Интервью & 10,0 & 11,7 \\
\hline 5 & Просветительский текст & 8,6 & 6.6 \\
\hline 6 & Расширенная новость & 7,1 & 23,1 \\
\hline 7 & Обозрение & 2,9 & 4,1 \\
\hline 8 & Очерк & - & 4,6 \\
\hline 9 & Журналистское исследование & - & 0,3 \\
\hline 10 & Другое & - & 0,2 \\
\hline & Всего & 100 & 100 \\
\hline
\end{tabular}

критически важная проблема здоровья и жизни в целом просто «провисает».

Сопоставление результатов опроса и контент-анализа показало, что в практической журналистике представлено более широкое понимание здоровья, чем можно было ожидать от анализа инфоповодов: в таких случаях, как говорится, жизнь берет свое, корректируя сознание. Однако налицо и несовпадение ряда позиций: журналисты видят проблемы, но фактически не решают их. В равной мере это касается и "хороших" тем (семейное счастье, "роскошь общения»), и «плохих» (зависимости). На первые нет времени, на вторые, может быть, желания. В целом же вывод, многократно представленный ранее, вновь актуален: несмотря на то, что теме здоровья уделяется внимание, повестка 30Ж в региональных СМИ в значительной мере пассивна, обеднена, невыразительна.

Жанры. Последняя из указанных характеристик нашла прямое отражение в обращении к жанрам публикаций. Проводя сравнение желаемых и реально используемых жанров, видим близкое совпадение мнений журналистов о наиболее эффективных жанрах для продвижения ценностей 30Ж и реальной практики региональных СМИ. Наиболее существенным отличием является различие в сравнении эффективности жанра «расширенная новость». На практике расширенная новость применяется в 23,1\% случаев, что поставило ее в реальности на второе место, хотя в анкетах журналистов она занимала лишь шестое место и оценивалась в 7,1\% (см. табл. 7).

Заметно отличается использование жанра репортажа - оценка его возможностей значительно расходится с практикой: опрос - 30\%, по факту - 17,7\%. Схожая ситуация со статьями: опрос - 18,6\%, по факту - 6,5\%. Очевидно, это объясняется уже отмеченным временным дефицитом и, как следствие, заменой запланированного репортажа и статьи расширенной новостью. Приходится фиксировать наличие неиспользованных возможностей.

Обратную картину наблюдаем с жанром очерка. В анкетах этот жанр не оказался в поле зрения журналистов - может быть, в силу понимания сложности его реализации, необходимости выхода в рамках жанра на обобщения и формулировки особых посланий. Однако на практике 4,6\% публикаций выполнены в жанре очерка, что свидетельствует о потребности у части журналистов творческого самопроявления на фоне повседневной рутины. Отметим: использование жанров сложной структуры, с эффектом авторского присутствия, с выходом на неочевидные суждения 
и обобщения, возможно и желательно в продвижении ценностей ЗОЖ. Этот прием позволяет уйти и от невыразительности несложных информационных форм, и от соблазна упрощенного морализаторства. Такие жанры требуют усилий и мастерства журналистов, но именно поиск нестандартной, опирающейся на личный опыт и профессиональные знания аргументации просветительско-мотивационного свойства был бы особенно полезен.

Анализ взаимосвязи между пониманием журналистами задач в области продвижения ценностей ЗОЖ и реализацией этих задач на практике позволяет сделать вывод о наличии определенных расхождений между состоянием профессионального сознания журналистов и реальной практикой. Журналисты готовы к работе, уровень понимания задач можно оценить как приемлемый, по ряду позиций высокий. На практике же удается реализовать далеко не все, что требуется и что желательно. По-видимому, можно говорить о реальных условиях работы (объективная сложность объекта, высокая загруженность, особенности редакционной политики, расстановка информационных приоритетов и пр.) и о личном отношении к теме (недооценка ее значимости, недостаток предметного знания, уровень профессиональных компетенций, недостаток времени и пр.). Названные обстоятельства препятствуют претворению в жизнь задач, осознанных и сформулированных самими журналистами.

\section{Ресурсный потенциал региональной прессы}

Наши исследования показали, что профессиональнаядеятельность региональных журналистов по продвижению ценностей здорового образа жизни может быть оценена как удовлетворительная. Среди областных газет, освещающих эту проблематику, не обнаружено изданий, которые были бы индифферентны по отношению к этой важной повестке. У журналистов имеются достаточно полные и современные установки по отношению к своей миссии укрепления здоровья аудитории. Публикации разнообразны по задачам, инфоповодам, тематике, жанрам; к работе привлекается пул экспертов. В то же время потенциал региональных СМИ гораздо богаче.

Контент-анализ показал, что количество и объем публикаций о З0ж в региональной прессе мог бы быть более значительным: сегодня их всего четыре-пять в месяц, при этом они главным образом информируют о мероприятиях, акциях, а также разовых событиях. Редакционная политика региональных СМИ, определяемая их владельцами и требованиями рынка, нередко вытесняет из информационного пространства проблемы 30Ж населения. Количественный недостаток публикаций, очевидно, свидетельствует о неполном понимании руководством региональных СМИ важности и неотложности участия в решении этой национальной задачи.

В региональной повестке 30Ж немало положительных сторон, но имеется и ряд недостатков: недооценка значимости здоровья и образа жизни в традиционных жизненных сценариях большинства граждан; чрезмерное следование принципам патерналистской социальной политики, осуществляемой властными структурами; недостаточная компетентность журналистов в вопросах 30Ж; неполнота, несбалансированность, пассивность повестки 30ж; неразвитость профессиональных методов в работе над текстами по проблематике Зож (ограниченность инфоповодов, пассивность в использовании методов получения информации, жанровая несбалансированность, склонность к морализаторству в использовании аргументации); недостаток внимания к ряду сущностных моментов в оценке ЗОЖ (зависимости, семья, психология, работа, среда); ограниченность в использования потенциала коммуникации с аудиторией; слабая организационная активность в работе с аудиторией. 
Полученные результаты дают возможность сформулировать основные рекомендации для журналистов, пишущих на темы 30ж:

- продвигать современные представления о здоровье, делая акцент на личной ответственности, разъяснять ограниченность надежд на опеку со стороны внешних акторов;

- увеличить объемы, расширить тематику публикаций на темы здоровья;

- быть более инициативными в выборе инфоповодов для продвижения ценностей и мотивации к 30Ж; следует существенно увеличить количество публикаций по данной тематике;

- повышать удельный вес статей, очерков, обозрений, интервью о зависимостях, семье, психологии и окружающей среде, являющихся реальной мотивацией к ЗОж;

- избегать прямого морализаторства в публикациях, модернизировать способы аргументации;

- активнее привлекать экспертов в качестве авторов и акторов публикаций;

- давать больше публикаций о положительном опыте, в том числе зарубежном;

- вести постоянные (ежедневные/еженедельные) интересные и привлекательные страницы (программы, рубрики) о 30Ж по возрастным группам, которые могут курировать профессиональные психологи и медики;

- повысить организаторскую активность редакций для вовлечения аудитории;

- совершенствовать методы активной двусторонней коммуникации СМИ и аудитории;

- предусмотреть возможность для повышения компетентности журналистов.

Сравнение данных дало в целом непротиворечивые результаты: сопоставляя полученные значения в разных проекциях, мы приходили к одинаковым или близким по сути выводам, которые свидетельствуют об их релевантности. Таким образом, удалось выявить как сильные, так и слабые стороны журналистской практики региональных средств массовой информации в области продвижения ценностей здорового образа жизни. Проведенное исследование показало, что для решения важнейшей профессиональной задачи - эффективной медиарепрезентации ценностей здорового образа жизни - современное информационное пространство требует от журналиста более глубоких знаний и новых умений, необходимость повышать убедительность предлагаемой аудитории информации и заботиться о ее привлекательности и доступности.

\section{Примечания}

${ }^{1}$ См.: Всеобщая декларация прав человека. Режим доступа: https://www.un.org/ ru/documents/decl_conv/declarations/declhr.shtml (дата обращения: 11.03.2020); Европейская социальная хартия. Режим доступа: https://www.coe.int/ru/web/ moscow/evropejskaa-social-naa-hartia (дата обращения: 11.03.2020); Конституция Российской Федерации. Ст. 4l. Режим доступа: http://constitutionrf.ru/rzd-1/gl-2/ st-4l-krf (дата обращения: 11.03.2020); О стратегии национальной безопасности Российской Федерации до 2020 года: Указ Президента Российской Федерации от 12.05.2009 № 537. Режим доступа: http://kremlin.ru/acts/bank/29277 (дата обращения: 07.03.2020); Об образовании в Российской Федерации: Федеральный закон от 29.12.2012 № 273-Ф3. Режим доступа: http://kremlin.ru/acts/bank/36698 (дата обращения: 17.03.2020); Об основах охраны здоровья граждан в Российской Федерации: Федеральный закон от 21.11.2011 № 323-Ф3. Режим доступа: https:// rg.ru/2011/11/23/zdorovie-dok.html (дата обращения: 11.03.2020). 


\section{Библиография}

Аристотель. Никомахова этика. М.: ЭКСМО-Пресс, 1997.

Афонюшкин О.С. Педагогические условия воспитания здорового образа жизни молодежи в учреждениях культуры: личностно-ориентированный подход: дис. ... канд. пед. наук. М., 2017.

Базелюк Н.Н. Социально-философские проблемы здорового образа жизни и индивидуального (валеологического) здоровья: дис. ... канд. филос. наук. М., 2008.

Беленькая Ю.П. Принципы формирования информационной повестки дня // Филология, журналистика и межкультурная коммуникация в диалоге цивилизаций: мат. Первой ежегодн. науч.-практ. конф. СКФУ «Университетская наука - региону» / под ред. С. В. Гусаренко. Ставрополь: ООО ИД «ТЭСЭРА», 2013. Ч. 2. С. 251. Режим доступа: https://docplayer.ru/26471157-Principy-formirovaniya-informacionnoy-povestki-dnya. html (дата обращения: 06.04.2020)

Бредихина Н.В. Ориентации населения на здоровый образ жизни: региональный аспект: дис. ... канд. соц. наук. Челябинск, 2006.

Бриленок Н.Б. Здоровый образ жизни как социальная практика // Изв. Саратовск. унта. Нов. сер.: Философия. Психология. Педагогика. 2016. Вып. 1. Т. 16. С. 5-9.

Вартанова Е.Л. Социальная репрезентация и новые медиа: к вопросу о переосмыслении теории повестки дня // Средства массовой информации в современном мире. 52-е Петербургские чтения. СПб.: Изд-во СПбГУ, 2013. С. 218-221.

Гален Клавдий. О назначении частей человеческого тела. М.: Медицина, 1971.

Гиппократ. О здоровом образе жизни // Наставления. Мн.: Современный литератор, 1998. С. 111-139.

Гладкий Ю.Н., Чистобаев А.И. Регионоведение. М.: Гардарики, 2002.

Кант И. Спор факультетов // Кант И. Собр. соч.: в 8 т. М.: Чоро, 1994. Т. 7. С. 57-136.

Касимов Р.А. Формирование регионального здоровьесбергающего образовательного пространства: дис. ... д-ра пед. наук. Ярославль, 2017.

Киршин Б.Н. Концепция региональной российской газеты: на примере «Челябинского рабочего»: автореф. дис. ... канд. филол. наук. Екатеринбург, 2006.

Конфуций. Беседы и суждения. СПб.: Кристалл-Терция, 1999.

Лазутина Г.В. Профессиональная этика журналиста. М.: Аспект Пресс, 2011.

Лазутина Г.В. Основы творческой деятельности журналиста. М.: Аспект Пресс, 2017.

Лебедев А.А. Региональные масс-медиа России: типология, структура и система. Формирование повестки дня // Региональные СМИ: проблематика, тенденции развития. Казань: Изд-во Казанск. ун-та, 2011. С. 56-94.

МакКуэйл Д. Журналистика и общество. М.: МедиаМир: Фак. журн. МГу, 2014.

Медиасистема России / под ред. Е.Л. Вартановой. М.: Аспект Пресс, 2017.

Мурзин Д.А. Содержательная модель издания // Эффективные модели региональной и муниципальной прессы. М.: Хроникер, 2008. Т. 1. С. 12-31.

Новак А.А. Особенности повестки дня региональных изданий: дис. ... канд. филол. наук. М., 2018.

Образцова И.В. Формирование здорового образа жизни населения как фактор обеспечения экономической безопасности России: дис. ... канд. эконом. наук: 08.00.05. СПб.: Петербургск. гос. ун-т экономики и финансов. 2010.

Платон. Тимей // Платон. Собр. соч.: в 4 т. М.: Мысль, 1994. Т. 3.

Прохоров Е.П. Введение в теорию журналистики. М.: Аспект Пресс, 2011. 
Свитич Л.Г., Смирнова О.В., Ширяева А.А., Шкондин М.В. Газеты средних и малых городов России. Социологическое исследование: опрос редакторов и журналистов. М.: Фак. журн. МГУ, 2015.

Стрига Е.А. Продвижение ценностей здорового образа жизни в российской прессе: исследовательские перспективы // Соц.-гуманит. знания. 2018. № 12. С. 158-166.

Фокина О.А. Региональная повестка дня в общероссийских печатных СМИ: дис. ... канд. филол. наук. М., 2013.

Фомичева И.Д. Социология СМИ. М.: Аспект Пресс, 2012.

Фролова Т.И. Гуманитарная повестка российских СМИ. Журналистика, человек, общество. М.: МедиаМир, 2014.

Шкондин М.В. Система средств массовой информации как фактор общественного диалога. М.: Пульс, 2002.

Шустер О.С. Психология здорового образа жизни и средства массовой информации: дис. ... д-ра психол. наук: СПб., 2005.

Andrew P., Marivic L. (2011) A Partnership for Health: Working with Schools to Promote Healthy Lifestyle. Australian Family Physician 40 (12): 1011-1013. Режим доступа: https:// search.informit.com.au/documentSummary; $d n=687235174340077$;res=IELHEA

Borowiec A., Lignovska I., Slonska Z. (2016) Global Health Promotion in Between Audience Mentality and Attitudes Towards Healthy Lifestyle Promotion in the Mass Media. Global Health Promotion 23 (3): 36-44. Режим доступа: https://journals.sagepub.com/doi/ abs/10.1177/1757975914567514

Bothmer M., Fridlund B. (2005) Gender Differences in Health Habits and in Motivation for a Healthy Lifestyle Among Swedish University Students. Nursing \& Health Sciences 7 (2): 107-118. Режим доступа: https://onlinelibrary.wiley.com/doi/abs/10.1111/j.14422018.2005.00227.x

Brouwer W., Brug J. (2011) Which Intervention Characteristics are Related to More Exposure to Internet-Delivered Healthy Lifestyle Promotion Interventions? Journal of Medical Internet Research 13 (1). Режим доступа: https://www.jmir.org/2011/1/e2/

Chiarelli F., Fulcheri M. (2016) Technology-Based Intervention for Healthy Lifestyle Promotion in Italian Adolescents. Annalidell'IstitutoSuperiore di Sanità 52 (1): 123-127. Режим доступа: http://www.annali-iss.eu/article/view/178

Danylevich M., Hribovska I. (2015) Organizational Conditions of Healthy Lifestyle Promotion for Arts Students. Journal of Physical Education and Sport 15 (2). Art 34, pp. 218-224. Режим доступа: https://efsupit.ro/images/stories/nr2.2015/Art34.pdf (дата обращения; 04.12.2019).

Ford E. (2019) Stress, Burnout, and Moral Injury. The State of the Healthcare Workforce. Journal of Healthcare Management 64 (3): 125-127. Режим доступа: https://journals.lww. com/jhmonline/Fulltext/2019/06000/Stress,_Burnout,_and_Moral_Injury_The_State_ of.1.aspx?WT.mc_id=HPxADx20100319xMP(accessed: 06.12.2019)

Jacobson D., Kelly S. (2011) Correlates Among Healthy Lifestyle Cognitive Beliefs, Healthy Lifestyle Choices, Social Support, and Healthy Behaviors in Adolescents. Journal of Pediatric Health Care 25 (4): 216-223. Режим доступа: https://www.sciencedirect.com/science/ article/abs/pii/S0891524510000490 (дата обращения: 06.12.2019). 